\title{
Urban Habit Inboiling Drinking Water: A Study Drom Kampung Salo Sub District, Kendari, Indonesia
}

\author{
Fikki Prasetya ${ }^{1}$, Linda Ayu Rizka Putri ${ }^{2}$, Riska Mayangsari ${ }^{3}$ \\ \{fikki.prasetya@uho.ac.id ${ }^{1}$, lindarizkaputri@outlook.com² ${ }^{2}$,riska.mayangsari28@gmail.com ${ }^{3}$ \} \\ ${ }^{1}$ Faculty of Public Health, Halu Oleo University, Kendari, Indonesia \\ 2,3 STIKES Karya Kesehatan, Indonesia
}

\begin{abstract}
Boiling drinking water becomes habit following the raise of the worry about drinking water hygiene. However, the increase of bottled water production and water refill depot affected the habit of boiling drinking water. This study aimed to analyse the habit of urban community regarding boiling drinking water with respect to the source of drinking water and education level. Cross sectional study was conducted on urban society in Kampung Salo subdistrict, Kendari, Indonesia. A number of 100 respondents were included in the study by mean of questionnaire. We employed a logistic regression to analyse the factors contributed to the habit of processing drinking water in the urban society. Results showed that there was no any significant effect between the habit of boiling drinking water with the source of drinking water $(p=0.999)$ and education level $(p=0.078)$. Conclusion : the source of drinking water and education level do not associate with the habit of boiling drinking water.
\end{abstract}

Keywords: Drinking Water, Urban Habit, Ready-to-Drink Water.

\section{Introduction}

Water is a major need to increase public health status as it becomes a media for transmitting water-borne disease, especially digestive tract disease [1], and so does drinking water. In developing countries, infectious disease is correlated with contaminated drinking water source [2]. Diarrhea is among the well-known water-borne diseases which is exacerbated by poor sanitation and hygiene and mostly vulnerable for children in the developing countries [3]. Moreover, the habit of not boiling water before drinking it is known to be a risk factor for diarrhea [4].

Globally, there had been an increase of diarrhea incidence and mortality in children during a period of 2015-2017. In 2015, diarrhea caused 688 million morbidities and 499,000 mortalities in children under five year of age. Meanwhile, about 1.7 million cases and 525,000 mortalities were attributable to diarrhea [5]. Boiling water has become a need on a daily basis following the raise of awareness about the quality of drinking water. Approximately 1.2 billion people worldwide process drinking water by boiling the water [6]. Boiling water can kill pathogens and microorganism transmitted through water as well as decrease the incidence of diarrhea [7].

Drinking water is either the processed or non-processed water fulfilling the health requirement and can be consumed directly. Drinking water is safe for health when it meets physical, microbiological, chemical, and radioactive requirements as additional parameters. The importance of water is supported by the increase of the population, the higher the population, the higher the demand for drinking water [8]. More than 75 million people in 
Indonesia are still difficult to access safe and healthy water, furthermore more than 100 million still have no access to proper sanitation facilities. Without an access to clean water, people have to either buy bottled water or boil the water [9]. Meanwhile, access to drinking water source in urban area decreased from $49.82 \%$ to $40.52 \%$. This decrease was exacerbated by the increase of bottled water and re-fill water as the main sources of drinking water [10].

Boiling water is the most common way for Indonesian as an alternative on processing household drinking water. Previous study found that the habits of boiling drinking water in the rural communities are higher than their urban counterparts [11].

Someone's habit is influenced by his education level. People with higher education will tend to maintain health by promoting hygiene and sanitation of drinking water consumed [12]. Choice for household water treatment, including boiling, chlorination and filtration, has been shown effective in improving drinking water quality and preventing diarrheal disease among vulnerable populations [13].

Based on the preliminary study in Kampung Salo, most people boiled their water as it had become their habit since ages and claimed that the taste of boiled water is better than re-filled or bottled water. This phenomenon had inflicted authors to conduct study which aimed to analyse the habit of boiling drinking water in urban community in association with the source of water and education level.

\section{Methods}

Focus of the study was processing drinking water through a habit of boiling water in relatively characterized in urban community in subdistrict Kampung Salo, Kendari, Indonesia. A cross sectional study design was made to gain data retrospectively which were completed and measured during the study period. The total sample was 100 respondents. Data were collected by means of questionnaire with multiple choice. The enumerator conducted preliminary interview to explain the aim of the study and to ask for informed consent.

Baseline characteristics were presented as percentage for categorical data. We employed a logistic regression to determine the association between the habit of boiling drinking water with the source of drinking waterand education level as well as to determine the most influential factor in boiling drinking water simultaneously. A two-sided $p$ value $<0.05$ was used to determine the significance. We carried out all the analysis in SPSS version 25 (SPSS, Inc).

\section{Results}

Base line characteristics of the study population

Table 1. Base line characteristics of 100 subjects at Kampung Salo subdistrict

\begin{tabular}{lc}
\hline \multicolumn{1}{c}{ Variable } & Percentage (\%) \\
\hline Women & 87 \\
Education level & \\
High school & 56 \\
College & 4 \\
Bachelor & 8 \\
\hline
\end{tabular}




\begin{tabular}{ll}
\hline The sources of water & \\
Tap water & 24 \\
Underground water & 17 \\
Well & 14 \\
Water spring & 21 \\
Refilled water & 17 \\
Bottled water & 2 \\
Surface water & 5 \\
Boiling drinking water & \\
Yes & 80 \\
\hline
\end{tabular}

Table 1 shows that the majority of samples were women $(87 \%)$. Most of the samples graduated from high school (56\%) and the least was college graduation (4\%). Regarding the sources of water, tap water was the most favourable (24\%), while only $2 \%$ of the samples used bottled water as the source of water. With respect to the habit of boiling the water, most of the samples boiled their drinking water before consuming it.

Association between the habit of boiling water and the source of water, education level and the reason of not boiling water.

As depicted in Table 2, there was no association between the habit of boiling drinking water and education level and the source of drinking water, $p$ value was 0.692 and 0.184 respectively.

Table 2. The association between the habit of boiling water and the source of water, education level and the reason of not boiling water

\begin{tabular}{llc}
\hline \multicolumn{1}{c}{ Variables } & \multicolumn{1}{c}{ Wald } & Sig \\
\hline Education level & 3.044 & 0.693 \\
Pre-school & - & - \\
Elementary & .000 & 1.000 \\
Junior high & .000 & 1.000 \\
Senior high & .000 & 1.000 \\
College & .000 & 1.000 \\
University & .000 & 1.000 \\
The source of drinking water & 8.824 & .184 \\
Tap water & - & - \\
Underground water & 1.131 & .288 \\
well & .314 & .575 \\
Water spring & .180 & .671 \\
Refilled water & 3.633 & 0.057 \\
Bottled water & .173 & .678 \\
Surface & .000 & .999 \\
\hline
\end{tabular}

\section{Discussion}

Overall, the habit of boiling water which is one of the domestic treatments to retrieve more hygiene and microbiological hazard-free water has become a basic need. By boiling the water, respondents assumed that it can help reducing the risk of pathogen exposure that may cause water-borne disease, such as diarrhea and many more. Boiling is a practice commonly used to treat water for drinking by households [14]. Unlike the urban communities in 
developed countries such as China where drinking water has been treated with modern appliance such as modern electrical heater [15], the respondents of this study still maintain traditional water treatment by boiling it using stove or coal fire although a study found that microbiological contamination is still potential through contact of stored drinking water with the hands [16], and frequent hand contact in large families increases the risk of contamination of water for drinking stored in containers [17].

Several sources of drinking water used by Kampung Salo community are tap water, underground water, well, water spring, refilled water, bottled water, and surface water. Of those sources, re-filled water was the most interesting source to analyze. Refilled water has been widely available throughout water depot in urban community. However, this availability did not influence the habit of boiling water in urban society represented by samples from sub district Kampung Salo. Although it has been stated in several literatures that refilled water should have fulfilled the quality standard for ready-to-drink water and therefore there is no special treatment required before drinking the water and become one of the existing clean water facilities [18], we found a different result with respect to boiling water. There are still some concerns of microbiological contamination such as pathogen bacteria contained in unboiled water which may cause water-borne disease. A study by Sari et al (2018) about the source of water in urban slum settlement Bandung found that most of the well and half of bottled and refilled water were contaminated by microbiological bacteria [19].

Boiling water is a traditional way assumed to be effective to reduce contaminant, and thoroughly improves the quality of water [20], and microbiologically effective [15]. In developing countries including Indonesia where integrated processing systems of drinking water for community are sparse, the habit of boiling water as a treatment in urban community is required and mainly due to the worry of microbiological contaminant in the drinking water.

This habit is different in those who consumed ready-to-drink water such as bottled water. The abundant availability of bottled water for any kind of brand especially in Kota Kendari gives alternative to urban society to choose bottled water. Community believe that bottled water is hygiene as it was processed and tested with a good standard by the water company to ensure water hygiene. Therefore, people are no need to undergo special treatment by boiling the water before drinking.

The result of this study showed that the source of consumed water either ground water, tap water, spring water, refilled water or bottled water was treated differently. The refilled water obtained from water depot was considered less safe from microbiological contaminant and some respondents assumed that it required treatment by boiling the water before it was consumed to avoid water-borne-disease. This treatment was also applied on the other source of water such as well, ground water, spring water and tap water. Although believe of low contaminant in bottled water was in contrast with refilled water, overall, the respondents considered special treatment for drinking water for most of water sources. This speculation supported our finding that there was no association between the habit of boiling water and the source of drinking water.

With respect to education level, we found no association between the habit of boiling water and education level. Although scientifically educations are mostly related to the habit of health [22], we found a slightly different result in our study. Education level of respondents did not directly influence the habit of urban society in processing water before it is consumed. Therefore, it can be concluded that the high or low education level will not affect the habit of boiling drinking water. We speculate that the most logical explanations for this result are because of boiling water has become habits and people in Kampung Salo consider that boiled water tastes better than refilled water. 
The habit of boiling water is believed to reduce the water contamination. The raise of awareness of microbiological contamination in un-boiled water has become concern of people in Kampung Salo and has inflicted them to boil the water to overcome the issue of drinking water hygiene. This habit showed that, even though people in Kampung Salo are considered urban community which represent most semi-traditional characteristic of urban community in Kendari in general, boiling drinking water still becomes habit descended from times to times and substantially implied the culture practiced by generations and maintained over times [21].

Although this finding suggests there should be improvement in the quality of refilled water which ideally is safe to be directly consumed, this recommendation still needs to be supported by other findings. The weakness of our study was limited subjects for research which were only represented by people living in Kampung Salo. A broader scope of study subject is required to attain a more accurate result and generalize the finding about urban habit in boiling drinking water in developing countries such as Indonesia.

Acknowledgement. The authors would like to thank people who have contributed to this research. We acknowledge the head of subdistrictKampungSalo for giving access and social support to the community to be actively involved in this study, KarangTarunaKampungSalo for actively involved during data collection. Thank you for Lita, Titin, Abrian, Rahmi, Ijum, NiluhAntari, Sherin, Winda and Riswan who have participated in research administration and data collection.

\section{References}

[1] Puspitasari, S., et al. "Hubungan kualitas bakteriologis air sumur dan perilaku sehat dengan kejadian waterborne disease di Desa Tambak Sumur, Kecamatan Waru, Kabupaten Sidoarjo." Jurnal Kesehatan Lingkungan 7 (1): 76-82, 2013.

[2] Lee, K-J.and Yoon, YS. Assessment of drinking water and sanitation habits in rural Tikapur, Nepal. Rural and Remote Health 13. pp. 2401, 2012.

[3] Rufener, S., et al. "Quality of drinking-water at source and point-of-consumptiondrinking cup as a high potential recontamination risk: a field study in Bolivia." Journal of health, population, and nutrition 28 (1): 34, 2010.

[4] Arimbawa, IW. and Dewi, KA. The Association between habitual and envrinmental factors toward the incidence of diarrhea in Sukawati village, Gianyar, Bali. Medical Science cores, 2016; 6 (1). pp.8-15, 2016.

[5] WHO. "Why Children are Still Dying and What Can Be Done". New York: WHO, 2017.

[6] Brown, J. and M. D. Sobsey. Boiling as household water treatment in Cambodia: a longitudinal study of boiling practice and microbiological effectiveness. The American journal of tropical medicine and hygiene 87 (3). pp. 394-398, 2012.

[7] Tao, T. and K. Xin. Public health: A sustainable plan for China's drinking water. Nature News (7511). pp. 511-527, 2014.

[8] Parimin, M. and M. U. M. Putra. "Analysis of factors associated with the demand of refilled water in Binjai." Journal of Wira Ekonomi Mikroskil: JWEM 6 (2): 103-112, 2017.

[9] Sinara, L. and S. Siphana. Indonesia-Third Water Supply and Sanitation for Low Income Communities (PAMSIMAS) Project." UNDP-Water and Sanitation Program; field note, 2012.

[10] Indonesian National Development Planning Agency. Report on the Achievement of the Millennium Development Goals in Indonesia. Jakarta, Ministry of National Development Planning, 2012. 
[11] Irianti, S. and P. Prasetyoputra. "Use of unsafe cooking fuels and boiling practice among Indonesian households: Empirical evidence from the 2012 Demographic and Health Survey." Indonesian Journal of Health Ecology 14 (3): 181-194, 2015.

[12] Hairani. "Correlation among mother's knowledge and practice of boiling drinking water to the incidences of toddler diarrhea in Puskesmas Baringin Tapin District." JHECDs, 3 (1), hal. 10-14, 2014.

[13] Freeman, M.C., Trinies, V., Soisson, S., Mak, G., and Clasen, T. : Promoting Household Water Treatment through Women's Self Help Groups in Rural India: Assessing Impact on Drinking Water Quality and Equity. PLOS ONE. Volume 7, Issue 9. Pp : 1-9, September, 2012.

[14] Gundry,S., Wright,J., and Conroy, R. A systematic review of the health outcomes related to household water quality in developing countries. J Water Health. pp. 2:1-13, 2004.

[15] Cohen A, Tao Y, Luo Q, Zhong G, Romm J, Colford JM, Jr, et al. Microbiological Evaluation of Household Drinking Water Treatment in Rural China Shows Benefits of Electric Kettles: A Cross-Sectional Study. PLoS ONE 10 (9) . pp. 1-16, 2015.

[16] Revett, A.F., Carter, R.C., and Tyrrel, S.F. Mechanisms leading to postsupply water quality deterioration in rural Honduran communities. Int J Hyg Environ Health. Vol. 208. pp. 153-161, 2005.

[17] Seino, K., Takano, T., Quang, N. K. L.,Watanabe, M., Inose, T., and Nakamura, K. Bacterial quality of drinking water stored in containers by boat households in Hue City, Vietnam. Environ Health Prev Med. Vol. 13. pp. 198-206, 2008.

[18] The Ministry of Health of Indonesia. The decree of the the Ministry of Health of Indonesia number 907/menkes/SK/vII/2006. Jakarta : Menkes RI, 2006.

[19] Sari, Sri Y. I., Sunjaya, Deni K., and Raksanagara, Ardini S. Water Sources Quality in Urban Slum Settlement along the Contaminated River Basin in Indonesia: Application of Quantitative Microbial Risk Assessment. Journal of Environmental and Public Health. Vol. 2018. pp . 1-7, 2018.

[20] Sodha, Samir V., Menon, M., Trivedi, K., Ati, A., Figueroa, M. E., Ainslie, R., Wannemuehler K., and Quick, R. Microbiologic effectiveness of boiling and safe water storage in South Sulawesi, Indonesia. Journal of Water and Health. Vol. 09 No. 3. Pp. 577-583, 2011.

[21] Nowak, M.A. Physical Culture Patterns in the Lifestyle of the Polish Society. Pol. J. Sport Tourism. Vol 20. pp. 3-7, 2013.

[22] Mocan, N., and Altindag, D. T. Education, cognition, health knowledge, and health behavior. Eur J Health Econ. Vol 15. pp. 265-279, 2014. 